\title{
ABISMO DE ROSAS: UMA METÁFORA VERTIGINOSA?
}

É lugar comum afirmar que a narrativa não nos oferece senão uma "visão", isto é, uma perspectiva necessariamente incompleta, lacunar, de um certo real. Como toda arte, visa à realidade estética, mas visa -a através dos meios que resultam de uma convenção a partir da qual se obtém o mundo representado como uma realidade mas também como uma ficção. Não se trata de um real "verdadeiro", mas de um discurso que reenvia, ele mesmo, ao mundo como problema.

As rupturas que se fazem à inteireza da convenção tumultuam o universo da narrativa, suspendem as regras tácitas do jogo de sua produção e compreensão, e obrigam o leitor a buscar novos elementos que lhe permitam fruir este "real" representado de modo estranho.

Entre narrador e narrado, por exemplo, nas narrativas em $3{ }^{\text {a pessoa as }}$ relações convencionais ditam que, estando as personagens em situação de diálogo, o narrador, ao interferir em sua fala, o faz enquanto ausente, e seu comentário dirige-se ao leitor e é, em princípio, desconhecido das personagens.

No conto "Abismo de Rosas" (que dá nome à obra), o diálogo direto predomina; falam o doutor e a mocinha, e a situação é a de uma peleja amorosa .

(Ela) - "Parece um menino. Só que cabeludo.

(Nar.) - Toda nua, de salto alto.

(Ela) - Correntinha também é roupa?

(Nar.) - Sem poder cobrir os três seios com duas mãos.

(Ele) - Que é essa cruzinha?

(Nar.) - O crucifixo barato, presente do noivo.

(Ela) - É enfeite.

(Nar.) - O velho Jesus, quem diria, piedosamente virou-lhe o rosto. (Ele) — Esse noivo não existe." (p. 3).

Ora, quem falou em noivo foi um ele ausente, cujo papel é o de descrever o aspecto, os atos das personagens, podendo emitir juízos implícitos ou explícitos, mas se existem um $e u$ e um $t u$ em situação dialógica, de presença, no contexto narrativo, esse olho que os enxerga e a boca que deles fala apresenta-se num espaço distanciado que converge para o deles mas que não é o deles. 
Nesse caso, a informação do narrador não poderia chegar às personagens porque falam através de canais diversos.

Outro exemplo do mesmo conto:

(Ele) - "Diga que é bom.

(Ela) - É bom - com um sorriso - Obrigada .

(Nar.) - Ah, bandida. Ser baixinho é padecer numa coroa de espinhos. Hei de levar para o túmulo?" (p. 5).

Aqui, a fala da personagem masculina assimila a do narrador. Quem fala pela boca do narrador é o doutor baixinho. E repete a façanha mais abaixo:

(Ela) - "O que você fez, querido? Ai, amor...

(Nar.) - Vingado, eu, o pequenininho que nunca podia dançar com a moça mais alta. O baixinho de todas as paixões e nenhuma correspondida. Pardal nanico, por todas as tijiticas perseguido". (p. 5).

No final, no momento da separação do homem e da mulher, a fala do narrador é-lhe devolvida, retornando ao seu tom primeiro distanciado e irônico.

(Nar.) - "Ela vestida, penteada, pintada.

(Ela) - Agora não mereço um beijinho?

(Nar.) - Ficou na ponta dos pés. De boquinha torta para não encostar, um tantinho enjoado.

(Ele) - Cuidado o batom.

(Nar.) - Ela baixou a linda cabecinha, os dois pintassilgos abriram asas.

(Ela) - Adeus gostosão."

Estamos diante de duas contravensões: os presentes ouvem a voz de um ausente e respondem a ela; um dos presentes assimila a voz do ausente, falando em lugar dele.

Essa permutabilidade de falas, esse interceptar de vozes que podem manar de uma boca ou de outra, coloca a questão: quem é o sujeito da enunciação? quem o objeto?

As personagens masculina e feminina (doutor e mocinha) se contam em situação de diálogo — nesse caso, são simultaneamente sujeito de enunciação e objeto de enunciado, enquanto o narrador comenta as personagens ao mesmo tempo que apresenta índices que nos remetem a ele. Assim, apresenta-se como sujeito de enunciação em que o objeto são os outros (homem/mulher), e sujeito em que o objeto é ele próprio.

No caso das personagens, a relação sujeito-objeto é muito próxima, confunde-se, já que eles se contam pelo simples fato de estarem vivos. Poder-se-ia 
até mesmo dizer que, em determinado ponto, o sujeito perde-se no objeto.

Como as falas são esteriotipadas neste e nos outros contos, o eu que fala em verdade é falado, objeto de fala de um eu anônimo que se camufla pemanentemente para simular que o uso da linguagem equivale ao uso da liberdade.

Esse eu que detém o poder e que está para além da obra produzida é nela desmascarado, delatado, por um recurso sutil e hábil do autor que é exatamente o de criar o espaço da indiferenciação.

Produzindo seres e falas seriadas e utilizando da paródia (nas observações do narrador, nas falas das personagens, nos títulos, na repetição dos contos) que se incumbe de revelar o processo de repetição que está em sua base, vai-se compondo, na obra, uma forma de comportamento que é a de parodiar a existência, protelando sempre os gestos e o discurso que inscreveriam o $e u$ na História.

Desqualificados ontologicamente, desumanizados, as falas do narrador e personagens desenham um movimento lacerado pelo fantasma da fixação, algo como a retórica da atadura, do nó, do que priva o outro, rompendo uma distância necessária para a preservação da diferença e para o andamento convencional da narrativa.

Preservado este andamento, a autoridade do narrar é dada ao narrador - autor explícito da narrativa. Subvertida a hierarquia, quem está de posse do poder?

Desautorizado também o "velho Jesus" (p. 3), o poder é do mais forte.

E o autor, ao constituir a linguagem, implicitamente a aponta como atributo alheio, pertencente a uma esfera de agressão, cuja meta é a de transformar os seres em vampiros menores, subtraindo-lhes a própria voz.

Transformados em objeto, a fala das personagens perde a carga de individua,idade, podendo, por isso, ser absorvida pela do narrador que também se contamina nesse processo alienatório. Só ele, no entanto, consegue perfazer o caminho de volta porque se investe de uma tarefa crítica.

"O caçador pode ser caça" (p. 69), a reificação atinge a todos promovendo a degradação do corpo que o capitalismo reduziu a um objeto de uso como os demais produzidos pelas indústrias.

Degradado o corpo, o erotismo é compartimentado em três domínios: um o perigoso, regido pelo código penal; outro, pelo ministério da saúde e bem estar social; e o terceiro, pela indústria de espetáculos. 
O sexo, em Abismo de Rosas, é uma engrenagem a mais na enorme máquina da alienação. O corpo, transfo:mado em objeto mercável, dedica-se a distintas formas de associação sexual, todas absolutamente abstratas, porque nos colocam ante uma combinatória erótica na qual os corpos foram substituídos por mecanismos. O corpo converte-se, assim, em matéria abstrata, em número, me frase cujo sentido se evapora.

"Apenas desaparece Dios de la perspectiva europea, los cuerpos se conviertem en mecanismos o en frases vueltas sobre sí mismas" (1); o fluxo e o refluxo que iam dos corpos para a natureza reduz-se à esterilidade do sujeito que se toma a si mesmo como objeto de amor e 5dio (2).

Não é em vão que as narrativas dessa coletânea tratem tão amplamente de matéria homossexual. Os casais heterossexuais que viviam em obras anteriores a relação minada, imobilizada cada vez mais pelo ódio e pelo silêncio, transformam-se em pares do mesmo sexo, o que acentua o fato de - um ser especular ao outro, marcando, assim, de maneira mais aguda, a indiferenciação, a perda da identidade.

Ao sugerir uma vasta combinatória sexual, a obra remete, em verdade, - leitor, a uma espécie de erotismo solitário( embora ab:angendo os três domínios acima referidos), em que a distância entre o um e o outro é intransponível e, por isso mesmo, acentuada pelo nojo e pelo desprezo.

Confinados à autossexualidade e movidos por uma fantasia erótica mais assimilada dos meios dé comunicação de massas que despertada pela presença do outro -as personagens são todas elas fantasmas da Ópera (3), ousados no escuro e covardes à luz do dia, excitáveis ante um objeto sexual sem face que sequer lhes dirige o olhar.

"Se o guarda the desse voz de prisão, que alívio não seria. Dispensado de voltar no domingo, começar tudo outra vez. O tipo na cadeira da frente não olha para a tela. Agarra a mocinha com três mãos. Traz até o joelho a mão dela. Explora o braço, o seio, o vestido de musselina rosa. Beija a ponta dos dedos, come-lhe a unha, sopra-lhe a orelha. Mete o sapatão debaixo do sapatinho. Morde-lhe os dedos, faz que morda cs dele. Tudo sem olhar para o filme. Sem que ela olhe nem uma vez para ele." (p. 70).

Caminhando pela rua, um se reconhece no outro e todos, como o primeiro fantasma da Ópera, tem a face desfigurada, inidentificável.

(1) Octavio Paz e Julián Ríos, Solo a dos voces, Espanha, Editorial Lumen, 1973.

(2) Essa tomada do sujeito como objeto sexual é chamada por Freud de Narcisismo: "Le sujet commence par se prendre lui-même, son propre corps, comme objet d'amour". Ver, a propósito, Pour introduire le narcissisme, 1914.

(3) "O Fantasma da Opera" é título de um dos contos da coletânea. 
"Se o porteiro lhe perguntasse o nome, o óculo embaçado, você não saberia responder" (p. 71).

Impossibilitados de retornar ao corpo, refúgio seguro da própria identidade, perdem-se no objeto que são eles próprios, cerco autofágico de esterilidade e morte.

"Meu amor é uma cadela que espuma. Rodopia, boca raivosa, estala os dentes para morder o rabo. Agora entendo o que eu matava a tiro" (p. 62).

O objeto do amor violento é o próprio sujeito que, infletido sobre si mesmo, se autodevora.

Esse espelhamento autofágico traduz-se em vários aspectos da matéria narrativa: no homossexualismo, na seriação dos seres ("Saiu ao pai: jogo, bebida e mulher. Perdido como o pai." p. 63/ "Reconheço a expressão dolorosa: minha mulher que me olha ou minha mãe para o monstro de meu pai"? p. 54) persistindo em sua estrutura.

Neste ponto é significativa, por exemplo, a presença de diálogos em que os dois interlocutores concordam sempre, em que um provoca a fala do outro que praticamente monologa, enquanto o primeiro se exime de assumir uma pessoalidade que certamente conduziria o diálogo para uma direção diferente. É o caso da narrativa "O Velhinho Audaz do Trapézio Voador", em que um velhinho tarado conta suas aventuras ao doutor que funciona como mola propulsora do discurso do outro, sem, no entanto, colocar-se como $\mathrm{eu}$, vu porque se esconde, ou porque sua identidade se amalgama à de seu interlocutor. Cria-se assim uma forma de diálogo paradoxalmente monólogico que não chega a ser polêmico porque tem um curso, um desenvolvimento.

E também significativo o modo como se interrelacionam as narrativas. Por convenção, cada conto se constitui como uma unidade independente e opaca na relação com os demais.

Em Abismos de Rosas, um conto alude a outro, quer pela presença das mesmas personagens, quer pela repetição de situações, chegando, mesmo um a continuar o outro ("As Neves de Curitiba" e "O Elefante Vermelho"). Compondo um repertó:io, espécie de linha de produção, em que ora, numa narrativa, a personagem é contada, ora, noutra, conta, surpreendetemente, nenhum elemento fundamental é acrescentado.

Universo poroso, Abismo de Rosas organiza-se como um jogo de espelhos que, ao invés de constituir e consolidar a identidade do objeto refletido, retira-lhe a substancialidade reduzindo-o a sombra, sem dimensão de profundidade. Um conto narra o outro, repete o outro, é reflexo do outro, inflete sobre o outro, tecendo um espaço monológico que, reduzido à sua mínima ins- 
tância, vê-se representado em "O Bêbađo de Nossa Senhora", título que reúne uma série de contos-sínteses, quase-aforismas, resultado de um processo autofágico que repete, em sua desarticulação, a desarticulação do mundo.

Esses contos fragmentos poderiam ser lidos como a gênese dos demais que, a partir deles, se desenvolveriam na narrativa propriamente dita. Nesse caso, eles teriam função de esboço.

A melhor leitura, no entanto, parece ser a que os considera não o ponto de partida, mas sim o de chegada das demais narrativas que, por força de rodopios foram mordendo o próprio rabo até atingirem a redução depurada de "O Bêbado de Nossa Senhora".

"Desfruta-a sem dó: come a gordura, bebe a doçura e abandona-a com a pele dos dentes." (p. 57).

“- Está quentinho o café?

Entende que ela chama o outro de benzinho." (p. 56).

"- Como era boa a broinha de fubá mimoso de Maria da Luz!

- Boa mesmo era a roupinha de marinheiro dos teus oito anos.

— Broinha não há como a da Maria da Luz...

— Já não há, isso sim, roupinha de marinheiro." p. 54).

"Mordido pelo cachorro louco de ódio, quer morrer espumando e latindo para a mulher." (p. 55).

"A chuva sovina conta e reconta suas moedas nas latas do quintal! (p. 57).

Diluída a narrativa, a identidade das personagens, do narrador, constrói-se uma superfície que, por ilusão ótica, finge ser um abismo vertiginoso.

Berta Waldman 